\title{
JAPAN'S ENVIRONMENTAL POLLUTION ISSUES: 1950s TO 1970s
}

\author{
Artikharina binti Awang, Alias Abdullah, \\ Tengku Adeline Azura Tengku binti Hamzah and \\ Mohd Shahrizal bin Azhari
}

\begin{abstract}
In the early 1950s, Japan was seen as developing fast and had the fastest economy recovery after the devastation from the atomic bombing of Hiroshima and Nagasaki during World War Two. In the post-war era, Japan focused its resources in developing its industrial sector. Thus after the Second World War, Japan experienced a high level of economic development due to the availability of industrial competition and high investment rates in the country. Behind this fast economic growth, environmental pollution became more serious when industrial waste disposal began increasing over the years. Thus began the growth of residential movements of issues pertaining to environment pollution that led to policy changes in Japan. The study examines the extent to which environmental pollution became a catalyst in the Japanese public changing its orientation from economic interest to environmental conservation.
\end{abstract}

Keywords: environment, industrial pollution, resident movement and environmental policies.

\section{Introduction}

Japan's industrial activity started during the Meiji era (1868-1912), which was the beginning of the modernization period. During the Meiji era, the industrial sector was considered important for Japan because it contributed to the defence sector, which was the primary production of the industrial sector. The main mining activities were designed to obtain raw materials such as copper, which was the most important resource and the main export of Japan. Equally, mined resources were exported to other countries, which was 9.5 percent of the country's total income. In the $1890 \mathrm{~s}$, the environment suffered severely from large-scale mining activities ${ }^{1}$. For example, in the $1890 \mathrm{~s}$, Tochigi and Gunma residents were flooded by the Watarase River which was contaminated by Ashio mining activities ${ }^{2}$. Farmers suffered severely when their crops got destroyed and poisoned by waste from these mining activities in the Watarase River. Later, negotiations were held between the farmers and Ashio Copper Mines to reach an agreement for compensation of the damage suffered by the local population.

Although mining activities had a clear negative impact on the environment, these activities continued, especially after the Sino-Japanese War, when Japan tried to compete with bigger powers. Mining resources were essential to meet the needs of Japanese imperialism at that time. Environmental conditions deteriorated when sulphurous anhydride resulting from rapid mining activities was released to the environment. As a result, in 1896, when a major flood struck five

\footnotetext{
${ }^{1}$ Kichiro Shoji \& Masuro Sugai, "The Ashio Copper Mine Pollution Case: The Origins of Environmental Destruction" in Jun Ui (ed.), Industrial Pollution in Japan, United Nations University Press: Japan, 1992, p 18.

${ }^{2}$ Ibid, p 22.
} 
large districts and small towns, it caused 23 million yen worth of damage ${ }^{3}$. Shozo Tanaka, a member of the Diet of the Tochigi area, along with other volunteers began to organize a movement to stop the mining activities. This was considered to be the first ever Japanese citizen led movement ${ }^{4}$.

Despite efforts to stop such mining activities, the Japanese government's solution was related to payment of compensation, establishment of flood control system. Moreover a survey was conducted by the Ashio Copper Mines to control and monitor the pollution. As a result of the Ashio mining activities, it can be argued that locals did not have the influence and power to voice their opinion against Ashio Copper Mines that had firm support from the government. In the 1890s, government policies were more favourable to mining activities and environmental problems were seen as mere social problem, not under government's jurisdiction. By the 1900s, more industrial activities were in full swing and they became more diversified in order to contribute to Japan's economic development. At the same time, the contamination problem became more serious, when it not only affected the income of the local residents, but also their health.

\section{Pollution Problems in the 1950s}

After World War II, Japan bore the worst damage in two major cities, having Hiroshima and Nagasaki destroyed and Okinawa became a battle ground between Japan and the Allied Powers. With the end of World War II, the Japanese government with the assistance of the United States, gave priority to urban development to redevelop cities destroyed during the war. During times of war, Japanese policies emphasized military interests with 90 percent of industrial production for military purposes. But after the defeat of Japan and the impact of the peace treaty, all industrial production was intended to meet the needs of the local population. Thus after the second World War, Japan experienced a high level of economic development with the availability of rapid industry development and higher investment rates in the country. However, environmental degradation became more serious when industrial waste disposal increased year by year.

\section{Water Pollution Problem}

Water pollution first was detected during the Meiji era as a result of mining activities. In the 1950s with the development of heavy industries, Japan once again faced water pollution. In the past, water pollution from Ashio mining activities only jeopardized the livelihood of the local people, but this time around it also affected the ecosystem as well as health of the population. One such case was the Minamata river pollution.

\section{Minamata River Water Pollution}

Minamata disease spread in the mid-1950s caused by mercury poisoning in Kyushu ${ }^{5}$. Kumamoto farmers and fishermen became vulnerable to mercury poisoning when the Chisso Corporation Company started throwing mercury into the Minamata Bay. Mercury poisoning became a norm

\footnotetext{
${ }^{3}$ Ibid, p 27.

4 Ibid.

${ }^{5}$ Tadashi Kitamura, "History of Water Environmental Policy," Water Environmental Management in Japan, available at http://www.waternunc.com/jp/history_jp.htm, accessed May 19, 2012.
} 
among the locals who depended on the Minamata river. The Chisso Corporation, originally a producer of petrochemicals and plastics dumped 27 tons of chemicals between 1932 and 1968 into the Minamata Bay ${ }^{6}$. The Chisso Corporation, considered a successful Japanese entity, was negligent. It continued to maintain its development even after the defeat of Japan during World War II. More importantly, the Chisso Corporation brought rapid development into Minamata area.

However, in the mid-1950s, local residents began to suffer from cramps, deterioration of the nervous system, problems with communication, brain damage and loss of sanity. Dr Hajime Hosokawa, who worked at the Chisso Corporation hospital, reported these symptoms ${ }^{7}$. He found that the disease had a strong relationship with the local diet of fish. An investigation was conducted and the Minamata waters were found to be contaminated with toxic mercury dumped by the Chisso Corporation. However, the Chisso Corporation rejected the accusation and continued its operations. In 1958, the company changed its dumping policy from Minamata Bay to Minamata River to avoid any charges ${ }^{8}$. Eventually, the Minamata disease began to show signs among the local residents of Hachimon and Shiranui waters. In July 1959, a group of researchers from Kumamoto University wanted to study the cause of minamata disease from organic mercury poisoning, but they encountered opposition strongly from a group of researchers from the Chisso Corporation ${ }^{9}$. Dr Hosokawa was prohibited from doing further research on the causes of the disease and local residents were threatened by the management of Chisso Corporation ${ }^{10}$. Without government support and the Chisso Corporation denying the cause of the disease forced locals to protesting activities of the company. As a result, the Chisso Company continued to poison Minamata waters. This activity ceased only when techniques using mercury in the process of plastic products were stopped by other manufacturers of industrial enterprises in 1968. The Chisso Corporation was eventually tried for having poisoned the Minamata waters from 1932 until $1968^{11}$. According to the Japanese government's estimation, roughly 2,955 people suffered from Minamata disease and about 1,784 died ${ }^{12}$ as a result of mercury poisoning.

No one had ideas how to treat the disease when people started behaving strangely. Many referred to the disease as a "cat's dancing disease" because cats in the area showed strange behaviour patterns and died dramatically ${ }^{13}$. At that time, no one realized how dangerous the disease was because there was a lack of research and data collection coupled with the length of time it took for the symptoms to appear. Despite protests against the pollution of the Minamata waters from the activities by the Chisso Corporation, it did not fully affect the Corporation's operations. Further, local residents did not know how to fight big corporations. Since the Chisso Corporation is a company that had a strong influence in Kumamoto for paving the development of the area, allegations made against the entity was not taken seriously. The government supported or turned a blind eye to the unhealthy activities of the corporation which helped in the $g$ economic growth of the area. The rapid economic development that occurred in the 1950s in Minamata brought jobs

\footnotetext{
6 "Minamata, Japan Disaster," available at http://www1.american.edu/ted/MINAMATA.HTM, accessed 19 May 2012.

7 Ibid.

8 Ibid.

${ }^{9}$ Ibid.

${ }^{10}$ Ibid.

11 Ibid.

12 Mary Kugler, "Minamata Disease; Thousands poisoned, disabled, and killed," Rare Dieases, available at http://rarediseases.about.com/od/rarediseases1/a/102304.htm.

13 Douglas Allchin, "The Poisoning of Minamata," Ships Education, available at http://wwwl.umn.edu/ships/ethics/minamata.htm.
} 
and boosted the economic growth of the area. Later, the growth resulted in environmental pollution which not only effected the source of income but also the health of locals.

\section{Jinzu River Water Pollution}

Another problem related to water pollution occurred in the Jinzu River in Toyama area (see Figure 1). The pollution in the Jinzu River was from cadmium poisoning due to mining activities. The impact of mining caused the poisoning of land and water resources in agricultural areas. Rice cultivated in the area contained high levels of cadmium. Therefore, many local residents were exposed to high cadmium poisoning that for a long time which caused a negative effect on residents' health. The mining activities were conducted in close proximity to the Jinzu River. Local residents around Jinzu River suffered from strange diseases called "itai-itai disease," denoting the pain borne by resident suffering from poisoning. The women were affected more than men as they suffered severe pain and had brittle bones. The disease was first identified as an epidemic in $1955^{14}$ and then an investigation was conducted to identify the causes. The initial discovery of the causes were unclear. In 1955, Shogo Hosoya observed the disease was caused by micro-organisms. A year later, Dr. Noboru Hagino said the disease was a bone related disease (osteomalacia) caused by lack of nutrition, but eventually changed his diagnosis upon finding the disease confined to Jinzu waters ${ }^{15}$.

After conformation of the disease being confined to Jinzu waters, further investigation revealed the disease was caused by high levels of cadmium poisoning from the content of heavy metals such as zinc in the river waters. Contamination occurred about $30 \mathrm{~km}$ from Kamioka mining, where heavy metal waste was continually dumped into the Jinzu river. This act contaminated water sources used by local residents in the Osawano-cho and Fucyu-machi areas where agricultural was the main activity. The water from the river eventually contaminated the soil and rice produce which absorbed cadmium three times faster than zinc ${ }^{16}$. Excessive intake of cadmium on a long term basis caused serious health problems, especially kidney problems and bone decay (osteomalacia) among residents.

The Kamioka Mining company was located upstream of the Jinzu river was based on tin and silver mining from the 17th century onwards. After the Meiji Restoration and the beginning of the modernization of Japan, the company started to mine zinc under the management of Mitsui Capital and from 1905, it became a major producer of zinc within Japan ${ }^{17}$. At the time, cadmium which is a by-product of zinc ore had no value to the industry, so Mitsui Capital just dumped the material into the Jinzu river. As a result, from the beginning of its operations, Kamioka Mining caused damage to crops and fisheries in the Jinzu River and this became much worse in the 1930s when the demand for zinc increased. Due to the contamination of the Jinzu river, in 1910, local residents in Toyama began suffering from the itai-itai disease.

\footnotetext{
14 "Preventative Measures Against Water Pollution: Jinzu River Toyama Prefecture," International Center for Environmental Technology Transfer, available at http://www.icett.or.jp/english/abatement/toyama/disease.html.

15 Ibid.

16 Ibid.

${ }^{17}$ Masanori Kaji, "Expert and Citizen Participation in the Pollution Control: The case of Itai-itai Disease in Japan," Ethics in Science and Environmental Polictics, Vol. 12, pp 99-111, 2012 doi: 10.3354/esep00126.
} 
Figure 1: Areas along the Jinzu River basin effected by mining pollution.

Fig. 1-2 Areas along the Jinzu River basin effected by mining pollution

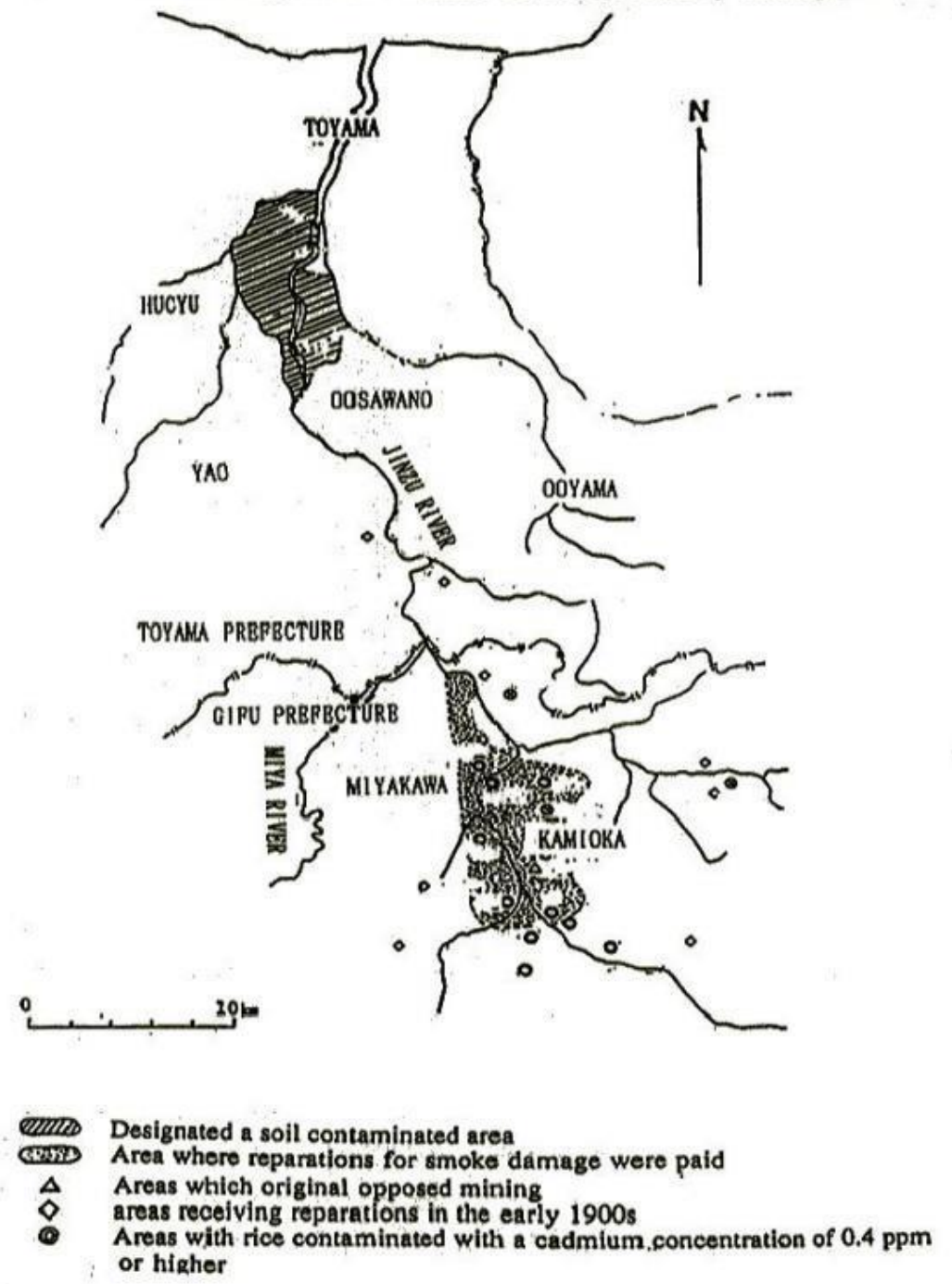

Dr Hagino Shigejiro, who first became aware of the disease in 1935 attributed the cause of it to the mining waste activities of the Kamioka Mining ${ }^{18}$. Dr Noboru Hagino who worked in Toyama Shinbun, conduct an investigation and found that all patients who worked near the Jinzu river showed signs of the same disease and suspected it was caused by the Kamioka Mining activitie. In 1957, he reported that the disease was caused by heavy metals such as zinc, but his report was criticized by other researchers. Then, with cooperation from Kin-ichi Yoshioka, an

18 Ibid. 
agronomist and June Kobayashi, a professor from the University Okoyama, Hagino conduct research to provide stronger evidence of itai-itai disease as a result from Kamioka Mining activities. However, local governments were not very cooperative in helping the victims of itaiitai disease. Finally in 1963, a research group funded by the government established under the Ministry of Health and Welfare and the Ministry of Education stated that the disease was indeed caused by cadmium poisoning and the source was from the Kamioka Mining managed by Mitsui Mining \& Smelting Co., Ltd. ${ }^{19}$

The victims of this pollution establish the Itai-Itai Disease Association in 1966 in Kumano district which was the worst polluted area in the Toyoma region ${ }^{20}$. With the cooperation of the association and a local lawyer, they filed a lawsuit against Mitsui Mining \& Smelting Co., Ltd. in January 1968 asking for payment for damages and compensation for the victims affected. The Mitsui Mining \& Smelting Co., Ltd. was found guilty and agreed to pay agricultural damages, clean the polluted areas, pay compensation to all victims of itai-itai disease and sign a Pollution Control Agreement. Under this agreement, the company was bound by Itai-Itai Disease Association rules where the association was given permission to inspect factories and mining areas at any time. Further, the company had to provide data on pollution when requested by the association as well as increase industrial waste management systems to avoid more pollution problems. It can be argued that the cadmium pollution issue in the Jinzu river was successfully addressed compared to the mercury pollution problem in the waters of Minamata. However, both these issues took a long time because action was only taken after the pollution reached serious levels.

Japan also has the problem of solid waste, especially waste disposal problem. In the 1950s, most of the solid waste disposed resulted from burning. Okinawa was the region where most burning solid waste happened through massive waste incineration. Japan is estimated to have 70 percent of the world's solid waste incineration. At the beginning of the program it was considered as a great solution to solid waste management mostly based on paper and wood. However, the innovative style of solid waste management caused a fresh problem in which composition of the waste was transformed and mixed with plastics and other materials that produced toxic gases when burned. Poisonous gases such as nitric oxide, hydrogen chloride and dioxin were generated by the burning program in Okinawa. Other problems derived from the solid waste management program was the burning of dangerous chemicals at one go which produced other chemicals which affected the health and environmental quality. This was coupled with the problem of ash produced at the combustion plant. This ash began to be absorbed into the ground and had an impact on the environment. For solid waste which cannot be disposed by burning, the waste was sent to open landfills and this caused the formation of excessive waste piles. This method was a short-term solution. There were four waste disposal sites in Okinawa and it generated huge waste piles within a short period of time. Disposal of waste in this way was short term. Japan faces the problem of finding new landfill sites because of its hilly geography and small size. The incinerators alone cannot resolve the issue of waste management in the long term.

\section{Environmental Pollution in the 1970s}

\footnotetext{
19 Ibid.

${ }^{20}$ Ibid.
} 
If the post-war era was the period of Japan's recovery, then in the 1960s it was the era of rapid economic development. At this time, industries focused on providing services and commodities for domestic use. In the 1950s most of the pollution was the result of mining activities but Japan's rapid economic growth era later was led by heavy industries. As a result, this led to environmental pollution in Japan where hazardous chemicals were released in high quantities continually. Further, economic expansion accelerated demand for goods, especially household products like television equipment, food, cars, etc. that caused the increase of domestic waste pollution that included metal, plastic, paper and glass, used in daily household activities. These were difficult to dispose of.

Heavy industrial activities, particularly in the automobile and manufacturing plastic products industries began to grow rapidly and led to the rapid growth of the Japanese economy in the late 1960s. This contributed to rapid employment opportunities for residents. However, the problem of contamination that occurred at the end of the 1960s not only affected one area but other areas that are close to it. Pollution and environmental issues gained the attention of local residents and they took action, especially when their government refused to take any measures against the polluters. The following highlights some of these environmental issues.

\section{Dokai Bay Water Pollution Problem}

Dokai Bay located in the north of Kitakyushu is rich in marine life which become a source of income for local resident since the 19th century. Dokai waters later was developed as a port and centre for the logistics industry. As an example, the Yawata Steel Works, located along the Dokai Bay was established in 1901, with support from the Japanese government ${ }^{21}$. After the establishment of Yawata Steel Works, other industries came into being in the area. Consequently, the level of water quality in the area became affected due to dumping of heavy industrial wastes in large quantities. Eventually the marine life in Dokai Bay became non-existent. From the 1960s onwards Dokai Bay became known as the "sea of death" as a result of chemical dumping activities that caused high levels of toxic in the water ${ }^{22}$. Incomes of fishermen began to be affected when the quantity of fishery resources declined sharply and later, the waters had zero habitats of marine life ${ }^{23}$. Fishing activities ceased and most of the locals were employed by factories around the Dokai Bay. Industrial wastes dumped into Dokai Bay contaminated the water around it with concentrations with high level of cyanide, cadmium, arsenic and mercury. A total of 22 factories were investigated, chemicals such as cyanide, phenol, cadmium, suspended solids (SS) and chemical erosion oxygen demand (COD) were found in the water. It was estimated that 135 tons of COD and 229 tons of SS were produced daily by untreated wastes dumping ${ }^{24}$. These chemicals that have caused high levels of toxic concentrations resulted in the extinction of marine life found in Dokai Bay.

Though quality and marine resources were badly affected, there was no governmental action taken. Hence, local residents began taking initiatives in carrying out conservation activities around Dokai Bay. Women indirectly played a role by disseminating awareness of the problem as

\footnotetext{
${ }^{21}$ Tetsuo Yanagi, Machiko Yamada \& Manabu Suzuki, "A Challenge of Water Purification in Dokai Bay, Japan," Marine Pollution Bulletin, Vol. 38, Issue 2, December 2009, pp 1063-1069, doi:

22 "The rebirth of the "Sea of Death": History of the recovery of Dokai Bay," Handbook of Environmental Mesures in Kitakyushu City, available at http://enviroscope.iges.or.jp/contents/76/eng/story/storyi2.htm, accessed 16 May 2012.

${ }^{23}$ Ibid.

${ }^{24}$ Ibid.
} 
well as vehemently opposing pollution activities that occurred in the city of Kitakyushu. In the mid-1960s, the Tobata Women's Association produced a documentary titled "Aozora ga Hoshii" or "We Want our Blue Sky Back" that highlighted industrial pollution and damage ${ }^{25}$. The documentary had a positive impact as it resulted in ongoing efforts to restore water quality in the area of Kitakyushu. The Kitakyushu Region Labor Union provided a positive report of the reduction in pollution levels in 1971 and highlighted the co-operation with the women's associations in carrying out awareness activities among the local residents ${ }^{26}$. Later the Kitakyushu Union Bay Management became responsible for the port and established the Dokai Bay Cleaning Study Group, which carried out large-scale purification activities at Dokai Bay. The cost of cleaning up was divided based on the Pollution Control Public Works Cost Allocation Law with 71 percent ( 1.28 billion yen) contribution from the industries and 29 percent $(0.52$ billion yen) from the government ${ }^{27}$. With clean-up activities, the level of toxic concentration in Dokai Bay decreased. With the cooperation of the local residents, local governments, universities, enterprises and government organizations, the environmental quality in Dokai Bay improved dramatically. The quality of water in Dokai Bay, formerly known as the "sea of death" improved greatly as a result of better control of industrial waste, construction of irrigation and waste management industry by all parties involved.

\section{Yahagi River Water Pollution Problem}

Pollution not only affected rural areas but also cities. Isshiki city is a place that depended on ocean resources. However a decrease in marine catch occurred when developments began to take place in mountainous areas in and around Yahagi River. The automobile industry in the upstream began dumping hazardous wastes into the Yahagi River which made the river muddy. People living in the port area became victims when the ocean sources became affected by pollution. Mikawa port especially, suffered severe losses when the marine life almost died. Farmers who depended on Yahagi water resources were affected due to the soil containing high levels of cadmium and the problem of excessive mud. Therefore, those affected complained to the developer in Yahagi River.

In 1966, the Yahagi River Water Preservation Council was established, a cooperative effort between farmers, fishermen and local residents, who depend on the Yahagi River for their daily lives $^{28}$. The members started an investigation on the quality of water and to find the source of Yahagi River pollution. In addition they also often patrolled at night to find factory workers who were illegally discarding waste into the river. The association became the representative for local residents to protest and build resident movements against pollution caused by the developer of the Yahagi areas. Even after the enforcement of the Water Pollution Prevention Act, the company was still throwing waste into the Yahagi River because there were no monitoring activities by the authorities. Eventually the Yahagi Water Council evolved into a consultative body in finding solutions for waste management. In 1977 through the efforts of this body, the state government decided that all companies who wished to conduct their activities in the area had to obtain consent from the Yahagi Yahagi Water Council. As a result of the cooperation between the populous living

\footnotetext{
${ }^{25}$ Carin Holroyd, Local Economy and the Futureof Environmental Sustainability in Japan and Asia: Osaka and Kitakyushu, The Asia-Pasific Journal: Japan Focus. From www. japanfocus.org/Carin-Holroyd/3844. Retrieved January 30, 2013.

26 "The rebirth of the "Sea of Death": History of the recovery of Dokai Bay," Handbook of Environmental Mesures in Kitakyushu City, available at http://enviroscope.iges.or.jp/contents/76/eng/story/storyi2.htm, accessed 16 May 2012.

${ }^{27}$ Ibid.

28 “Japan’s Pollution Experience: Bringing Water Back to Life,” TVE Japan, 1995.
} 
downstream and industrial companies conducting activities in the upstream of Yahagi River, the Yahagi River Rule was developed in the 1980s which played an important role in assessing the impact of development projects on the surrounding waters. ${ }^{29}$ All in all, the absence of an effective government to provide assistance and to take legal action over industrial companies in the Yahagi River forced local residents to take their own initiative to counter the environmental pollution activities. In doing so, the residents managed to discover and expose a series of pollution activities by various industries. As a result their association became a supervisory body around Yahagi waters for companies to comply with pollution control policies that had been agreed to.

\section{Tama River Water Pollution Problem}

In urban areas such as Tokyo, sewage from residential areas was the major cause of water pollution. The Tokyo metropolitan area began to show rapid housing development in the 1960s which impacted on the water quality in the city. Tama River is a major river that fed the Tokyo city and the main water source for local residents. With the increase in population in the Tokyo city, wastewater treatment plant was built on the banks of the Tama River to manage the increasing quantity of water sewage. However, the plant could not cope with the amount of sewage excess water which was released directly into the river. As the Tama River became contaminated, the use of high amount of chlorine to purify the dirty water became a norm.

To accommodate the growing urbanization, the government began a sewerage wastewater project from house to house. Wastewater was collected from one area and was treated through sewage system. But the construction of the sewage faced some problems because it clashed with the subway route. Therefore construction of sewerage system took a long time and at the same time the wastewater could not be treated fast enough and discharged directly into the Tama River. Besides, the development costs also increased each year, reaching an estimated two to five trillion yen. Further the operations ran slow compared with the population increase annually ${ }^{30}$. Because construction costs were too high, private sewage treatment system was introduced by Dr. Junko Nakanishi, a professor at Yokohama National University. He suggested that small cities should build their own sewage treatment system, and there was no need to connect sewer water into the larger sewers. This system is known as the "On-Site Water Treatment System" where the water treatment system is installed in each house. This system is able to treat used water in everyday life in every home that later could be reused and released into the environment. This system solved the sewage water problem for those who lived in rural areas more effectively. The proposed massive sewerage water treatment by the government was located 30 miles from the wastewater treatment plant and was estimated to take 20 years before the sewage system could function properly in the rural areas ${ }^{31}$. Because some local authorities in the smaller cities had begun building a community wastewater treatment system, in a short time every house had its own water treatment services. This sewage water treatment system, reduces the time, cost as well as solved the problem of excessive sewage and dirty water while preserving the natural environment.

\section{Solid Waste Problem}

\footnotetext{
29 Kenji Otsuka, Koari Fujuta, Yayoi Isono \& Motoyuki Mizuochi, "Governance for Water Environment Conservation: Implication for Japanese Experiences” in Kenji Otsuka (ed.), Building Effective Governance for Water Environment Conservation in China - A Social Experiment in Community Roundtable Meetings in the Tai Lake Basin, Chapter 4, 2009, p 5.

30 “Japan's Pollution Experience: Bringing Water Back to Life,” TVE Japan, 1995.

31 Ibid.
} 
In the early 1950s, solid waste problem arose from domestic consumption and the issue was solved by using the combustion system and waste collection by dumping into landfills. At the end of the 1960s, with the development of various industries, the number of problems related to solid waste landfill increased, Japan faced problems in finding suitable places as new dumping sites.

\section{Tokyo City Waste Problems}

Issues concerning solid waste was a major problem in major urban areas such as Tokyo. Only a small number of solid wastes could be disposed of. Moreover, solid waste dumping caused serious odour and hygiene problems to nearby residents ${ }^{32}$. Before the 1960 s, most of the solid waste consisted of wood and paper-based materials, but after the 1960s, the solid waste composition changed whereby it contained hazardous materials as a result of production and demand for various goods. With rapid economic development, the quantity of packed goods such as food cans and plastic containers increased dramatically. Plastic is a material that does not expire and releases harmful dioxide when burned. Therefore, when Garbage Law was enforced in 1954, every local government was responsible for managing its own waste. Until the 1970s, local residents began to separate solid waste themselves. As a solution, the Japanese began separating all solid waste, differentiating between bottles, cans, plastic and paper in order to recycle aimed at reducing the amount of solid waste in their respective areas.

\section{Nagoya City Solid Waste Problems}

Nagoya City faced solid waste disposal problems. Solid wastes were not separated but were grouped together, burned or buried to solve solid waste problem production that increases annually. This is because the Nagoya local government did not have a solid waste recycling system. Furthermore, private companies were not responsible for collecting solid waste as it did not generate profits. Hence, all solid waste collected were dumped at the landfills. In 1991, Japan established the Recycling Law, but due to the lack of full enforcement, Nagoya city was slow at implementing the idea of separating solid waste that could be recycled. To overcome the problem, the Fujimae coast, the only natural shoreline was proposed to be the new site for landfills. However, it received strong opposition due the importance of Fujimae coast to wild animal's ecosystem. The mass media also criticized Nagoya local government's failure on sorting solid waste that could be recycled. In 1998, Nagoya city cancelled its plans to make the Fujimae coastal area as an open landfill. Finally, the local government decided to reduce its waste disposal by 20 percent through the cooperation between the government, local companies and residents. These separate entities cme together to start a massive recyclable materials separation program ${ }^{33}$. In so doing, Nagoya city achieved its objectives in reducing the quantity of its solid waste in a very short time.

\section{Teshima Island Solid Waste Problems}

Starting in the late 1950s, Japan actively engaged in the automobile industry, especially heavy industry which later created the problem of automobile and heavy metal dumping activities.

32 “Japan's Pollution Experience: Bringing Water Back to Life,” TVE Japan, 1995.

33 Ibid. 
Automobile companied used remote areas with small population as dumping sites. One such example was Teshima Island, which had a small population consisting of farmers and fishermen. The island turned into an "island of waste" as more than 500 tons of industrial waste were dumped there illegally ${ }^{34}$. Industrial waste problem especially automobiles waste started to become a major problem in Teshima Island when the Sogo Kanko Kaihatsu company began dumping industrial waste there illegally in the 1970s. Dumping activity lasted for 30 years and led to health problems among residents together with odour pollution. Industrial wastes, consisted of automobile components such as heavy metals, batteries, engine. These materials produced chemicals such as dioxins, polychlorinated polychlorinated (PCBs), mercury, arsenic which polluted the island's soil, plants and underground water. Local resident of Teshima Island protested but were not taken seriously. When the Sogo Kanko Kaihatsu applied for a license to build a plant from the Kanagawa local government in 1975, local residents began their protesting, collecting 1425 signatures and wrote a petition to the Kanagawa district to oppose the construction of industrial waste processing plant $^{35}$. Initially the local government in Kanagawa refused to give the license but later gave its approval when the company made an appeal in 1977. The company promised it would not bring any hazardous industrial waste in the islands, but later Sogo Kanko Kaihatsu brought industrial wastes in high quantities from Osaka to Teshima Island. By early 1980s, local residents began a protest campaign but the government refused to help. Eventually health problems began to occur among the Teshima population due to open burnings of industrial waste. In 1990, the local police arrested six employees of the company for illegally dumping of industrial waste ${ }^{36}$. The company then was sued for violating the Waste Disposal and Cleansing Law policies. Failure of the local government in Kanagawa in addressing the issue, Teshima residents established the Congress of Teshima Residents against Industrial Waste. Teshima residents distributed pamphlets in front of the local government office, sent a protest letter and visited Kanagawa lawmakers for support and to increase awareness of the situation on Teshima Island. In 1994, the Environmental Disputes Coordination Commission was given the power to investigate and solve the problem of industrial waste and preserve the environment. At the end of the 1990s, local residents and the Kanagawa local government reached an agreement in implementing a new industrial waste process management and review system. The Kanagawa local government also apologized to local residents for allowing the contamination activity occurred for a long period of time. The local government also managed and cleaned all hazardous industrial waste found on Teshima Island that had occurred as a result of industrial waste dumping activities.

\section{Conclusion}

The Meiji era in 1868 was the beginning of Japan's modern era. At this time, the nation focused on its defence development in order to compete with other great countries. Mining activities contributed to the country's income that accommodated the national defence development. Although mining activities had a negative impact on the environment, it was not regarded as a

\footnotetext{
${ }^{34}$ Natsuko Matsuoka \& Togo Tsukahara, “An Island of Garbage in the Eco-Utopian Euphony viewed from the History of Japanese Environmental Policy,” available at http://homepage2.nifty.com/tsukaken/matsuokanatsuko.pdf, accessed January 29, 2013.

35 Hiroshi Maruyama, "Notes for EGEO 423 Pacific Rim: Sustainable Environment," Muroran-IT Academic Resources Archive, 2003, p 48.

36 "English Information of Teshima," available at http://www.teshima.ne.jp/blog-archives/000008.html, accessed January 30, 2013.
} 
serious problem compared to the development of defence. Pollution issues affected local agricultural resources. The government took the easy way out by paying compensation to local residents. After the defeat in World War II, the Japanese government policy changed and began focusing on economic development. Early 1950s saw the beginning of industrial pollution in Japan. Industrial development became more rapid with the use of chemicals in production activities. Industrial wastes discharged in high quantities affected the ecosystem and the health of local residents. Because the local government was not supportive, residents had to deal with issues of environmental pollution. Responses by the local residents in solving pollution issues were varied between 1950s and 1960s.

1950s pollution problems took a long time to find solutions. The government usually supported the industrial company which resulted in rarely toking any action against activities that contributed to pollution. In comparison, local residents took every effort to oppose the company responsible. Companies like Minamata Chisso Corporation were influential and had support from the local government, mostly between 1932 and 1968. Environmental pollution, which began in the 1950s not only destroyed sources of income but also affected the health of local residents. For example, the work done by Dr. Hajime Hosokawa and Dr. Hagino Shigejiro provided evidence that the cause of rare diseases suffered by residents was a result of industrial waste activities in local waters. It can be reasonably argued that the 1950s, environmental awareness was still at a low level. The industries and the authorities controlled information about pollution at all levels. As a result, many became unaware of environmental pollution that occurred for a long period of time. This meant action was rarely taken or delayed.

In the 1970s, changes took place in how the locals addressed environmental pollution problems. When environmental problems reached a serious level, local residents began to gather evidence, conduct investigations, seek help from experts in order to take legal actions and urge the government to change policies. In addition, because of the cooperation between various groups and workers, pollution eradicating movements became more effective. In the 1970s local residents successfully exposed companies responsible for the pollution through the accumulation of regular patrols, and data. Community organizations increased dramatically in the fight against polluters and urging government to intervene in solving environmental degradation. Examples of the Yahagi River, Dokai Bay, Nagoya solid waste problem and the Teshima Island cases indicates successes of community organization. Moreover, such movements garnered the attention of international organizations. Clean up activities increased in Japan which led to improved environmental quality. This could be seen in the cases of cleaning work carried out in Dokai Bay and Teshima Island. More importantly, local governments began to change their policies from supporting industrial interests to that of environmental protection. Hence, these changes brought about increased environmental awareness, influenced not only by government policies but also local communities and grassroots' environmental movements.

\section{References}

"VII. Rediscovery of the Minamata disease in Niigata", United Nation University. From http://archive.unu.edu/unupress/unupbooks/uu35ie/uu35ie0d.htm. Retrieved January 29, 2013. Carin H., "Local Economies and the Future of Environmental Sustainability in Japan and Asia: Osaka and Kitakyushu". From http://www.japanfocus.org/-Carin-Holroyd/3844. Retrieved January 30, 2013. 
, “Case 12: River Basin Management of River Yahagi - River Yahagi Method". From http://www. wepa-db.net/ngos/activities/japan/case12.htm. Retrieved May 27, 2012.

Douglas A., "The Poisoning of Minamata". From http://www1.umn.edu/ships/ethics/ minamata.htm. Retrieved May 19, 2012.

"English Information of Teshima". From http://www.teshima.ne.jp/blog-archives /000008.html. Retrieved January 30, 2013.

, "Experience of Kitakyushu City in Overcoming Pollution". From http://www.sbmc. or.jp/english /20041018/Kitakyushu_City_vol2_vol3.htm. Retrieved May 26, 2012.

Hiroshi M., "Notes for EGEO 423 Pacific Rim: Sustainable Environment", Muroran-IT Academic Resources Archive, 2003, pg. 48.

, “Japan's Pollution Experience: Bringing Water Back To Life”. From TVE Japan. 1995.

, “Japan's Pollution Experience: Island of Waste”. From TVE Japan. 1995.

"Jinzu River and Kamioka Mines". From http://www.icett.or.jp/english/abatement/ toyama/river /index.html. Retrieved May 20, 2012.

Kenji O., Koari F., Yayoi I., \& Motoyuki M., "Governance for Water Environment Conservation: Implication for Japanese Experiences" in Kenji Otsuka (ed.), Building Effective Governance for Water Environment Conservation in China -A Social Experiment in Community Roundtable Meetings in the Tai Lake Basin, Chapter 4, 2009.

Kenny E., "Where does our trash go?", Weekly Japan Update, February 7, 1998.

Kichiro S., \& Masuro S., "The Ashio Copper Mine Pollution Case: The Origins of Environmental Destruction" in Jun Ui (ed.), Industrial Pollution in Japan, United Nations University Press: Japan, 1992.

Mary K., "Minamata Disease; Thousands poisoned, disabled, and killed". From http://rarediseases.about.com /od/rarediseases 1/a/102304.htm.

Masanori K., "Expert and Citizen Participation in the Pollution Control: The case of Itai-itai Disease in Japan”. From www.csi.ensmp.fr/WebCSI/4S/download.../download_paper.php? Retrieved May 20, 2012.

, "Minamata, Japan Disaster". From http://www1.american.edu/ted/MINAMATA.HTM. Retrieved May 19, 2012.

Miyazawa N., "Minamata Disease A History of Japanese Government and Kumamoto Prefectural Irresponsibility". From http://aileenarchive.or.jp/minamata_en/aboutminamata/ index.html. Retrieved January 30, 2013.

Natsuko M., \& Togo T., "An Island of Garbage in the Eco-Utopian Euphony viewed from the History of Japanese Environmental Policy". From http://homepage2.nifty.com/tsukaken/matsuokanatsuko.pdf. Retrieved January 29, 2013.

Pradyumna P. K., Japan in the $21^{\text {st }}$ Century: Environment, Economy and Society, University Press of Kentucky: United States, 2005. Pg. 367.

"Preventative Measures Against Water Pollution; Jinzu River Toyama Prefecture". From http://www.icett.or.jp/english/abatement/toyama/disease.html. Retrieved May 20, 2012.

Stephanie R., "7 Biggest Environmental Disasters - Where Are They Now?" From http://ecosalon.com/7-biggest-environmental-disasters-\%E2\%80\%93-where-are-they-now/.

Retrieved May 19, 2012.

Tetsuo Y., Machiko Y., \& Manabu S., “A Challenge of Water Purification in Dokai Bay, Japan”. From http://www.sciencedirect.com/science/article/pii/S0025326X99001927. Retrieved May 25, 2012. 
, "The rebirth of the "Sea of Death": History of the recovery of Dokai Bay". From http://enviroscope.iges.or. jp/contents/76/eng/story/storyi2.htm. Retrieved Mei 26, 2012.

, "Water Environmental Management in Japan". From http://www.waternunc.com/jp /history_jp.htm. Retrieved May 19, 2012. 